\title{
Interannual variability of surface and bottom sediment transport on the Laptev Sea shelf during summer
}

\author{
C. Wegner ${ }^{1}$, D. Bauch ${ }^{1,2}$, J. A. Hölemann ${ }^{3}$, M. A. Janout ${ }^{3}$, B. Heim ${ }^{4}$, A. Novikhin ${ }^{5}$, H. Kassens ${ }^{1}$, and L. Timokhov \\ ${ }^{1}$ GEOMAR Helmholtz Centre for Ocean Research, Kiel, Germany \\ ${ }^{2}$ Akademie der Wissenschaften und der Literatur, Mainz, Germany \\ ${ }^{3}$ Alfred Wegener Institute for Polar and Marine Research, Bremerhaven, Germany \\ ${ }^{4}$ Alfred Wegener Institute for Polar and Marine Research, Potsdam, Germany \\ ${ }^{5}$ State Research Center - Arctic and Antarctic Research Institute, St. Petersburg, Russia
}

Correspondence to: C. Wegner (cwegner@geomar.de)

Received: 20 August 2012 - Published in Biogeosciences Discuss.: 20 September 2012

Revised: 8 January 2013 - Accepted: 11 January 2013 - Published: 20 February 2013

\begin{abstract}
Sediment transport dynamics were studied during ice-free conditions under different atmospheric circulation regimes on the Laptev Sea shelf (Siberian Arctic). To study the interannual variability of suspended particulate matter (SPM) dynamics and their coupling with the variability in surface river water distribution on the Laptev Sea shelf, detailed oceanographic, optical (turbidity and Ocean Color satellite data), and hydrochemical (nutrients, SPM, stable oxygen isotopes) process studies were carried out continuously during the summers of 2007 and 2008. Thus, for the first time SPM and nutrient variations on the Laptev Sea shelf under different atmospheric forcing and the implications for the turbidity and transparency of the water column can be presented.

The data indicate a clear link between different surface distributions of riverine waters and the SPM transport dynamics within the entire water column. The summer of 2007 was dominated by shoreward winds and an eastward transport of riverine surface waters. The surface SPM concentration on the southeastern inner shelf was elevated, which led to decreased transmissivity and increased light absorption. Surface SPM concentrations in the central and northern Laptev Sea were comparatively low. However, the SPM transport and concentration within the bottom nepheloid layer increased considerably on the entire eastern shelf. The summer of 2008 was dominated by offshore winds and northward transport of the river plume. The surface SPM transport was enhanced and extended onto the mid-shelf, whereas the bottom SPM transport and concentration was diminished. This
\end{abstract}

study suggests that the SPM concentration and transport, in both the surface and bottom nepheloid layers, are associated with the distribution of riverine surface waters which are linked to the atmospheric circulation patterns over the Laptev Sea and the adjacent Arctic Ocean during the open water season. A continuing trend toward shoreward winds, weaker stratification and higher SPM concentration throughout the water column might have severe consequences for the ecosystem on the Laptev Sea shelf.

\section{Introduction}

The Arctic summer sea ice cover is continuously decreasing as a result of climate change, accelerating in the record minima in September 2007 (e.g. Serreze et al., 2007; Comiso et al., 2008; Kwok et al., 2009) and 2012 (National Snow and Ice Data Center; http://nsidc.org). Climate models employing medium future greenhouse gas emissions predict that the Arctic Ocean will be seasonally ice-free by the end of this century (e.g. Boé et al., 2009; Tietsche et al., 2011). Larger open water areas due to reduced sea ice cover on the vast Siberian continental shelves in summer are expected to lead to increased sediment resuspension and coastal erosion, due to larger wind fetch and wave heights (e.g. Eicken et al., 2005; Carmack et al., 2006). Additionally, annual Arctic river discharge may increase by $10-20 \%$ under a doubled $\mathrm{CO}_{2}$ scenario (ACIA, 2005), accompanied by increased loads of freshwater (Zhang et al., 2012) as well as suspended 


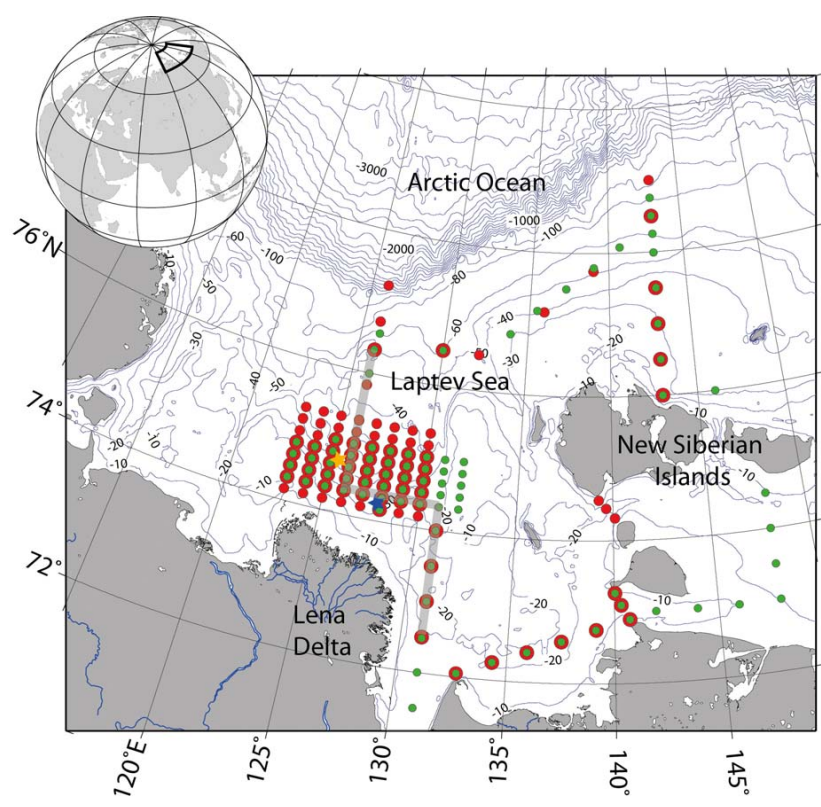

Fig. 1. Bathymetric map of the Laptev Sea shelf and the locations of the presented stations. Red circles indicate measuring sites during TRANSDRIFT XII expedition (22 August-22 September 2007) and green circles during TRANSDRIFT XIV (5-21 September 2008). The location of bottom-mooring station Anabar and Khatanga are marked by a blue and a yellow star, respectively. The solid line marks the cross-shelf section shown in Fig. 4.

and dissolved matter to the Arctic ecosystem. The export of turbid waters from rivers and coastal regions could enhance the delivery of nutrients to microalgal populations, but could also impair photosynthesis by scattering and absorbing sunlight (Retamal et al., 2008). A detailed understanding of the pathways of suspended particulate matter (SPM) is critical in order to draw the connection between sediment dynamics, optical properties and ecosystem dynamics under a changing climate.

The Laptev Sea shelf hydrography is strongly dominated by river discharge from the River Lena, with an annual freshwater input of $600-700 \mathrm{~km}^{3}$ (e.g. Létolle et al., 1993; RArcticNET, 2011). The riverine influence reveals a strong seasonality with highest freshwater input during and briefly after the spring breakup in June (Pivovarov et al., 1999). In summer the shelf hydrography functions like an estuarine system that derives its water and material from both terrestrial and oceanic sources (e.g. Wegner et al., 2005). The spatial distribution of the Lena River freshwater plume shows a strong interannual variability, mainly associated with positive and negative phases of atmospheric vorticity over the adjacent Arctic Ocean in summer (Guay et al., 2001; Dmitrenko et al., 2005; Bauch et al., 2009). The vorticity index is defined by Walsh et al. (1996): During a negative phase, when the mean summer atmospheric circulation is predominantly anticyclonic, the freshwater plume spreads northwards onto the Laptev Sea shelf (Dmitrenko et al., 2008). During positive vorticity anomalies and cyclonic atmospheric circulation, the riverine surface waters are transported eastward (Dmitrenko et al., 2008). It can be assumed that the surface distribution of SPM during open water season is closely connected to the distribution of the riverine surface waters. However, the relationship between SPM, nutrients and the distribution of riverine freshwater as well as the impact of turbidity on the ecosystem has not yet been established.

Even though the Arctic shelf seas are important in the context of climate change, especially regarding the increased export of turbid waters onto the shelves and their effect on primary productivity, there are only few field studies which focused on optical properties, mainly in the Canadian Arctic (e.g. Vasseur et al., 2003; Retamal et al., 2007, 2008), the northern North Atlantic and in the Greenland Sea (e.g. Stramska et al., 2003; Lund-Hansen et al., 2010). Historical measurements of SPM on the Laptev Sea shelf during the open water season are limited: Anoshkin et al. (1995) and Antonow et al. (1997) used hydro-optical measuring devices, which produced only relative values of SPM concentration on the Laptev Sea shelf, since in situ calibration of the hydro-optical data was not available at the time. These authors and others (Hoelemann et al., 1995; Burenkov et al., 1997; Lisitsin et al., 2000; Wegner et al., 2003, 2005) described the existence of two nepheloid layers, i.e. layers with increased SPM concentration. The formation and concentration of the surface nepheloid layer are mainly related to the abundance of phytoplankton and zooplankton (e.g. Abramova and Tuschling, 2005). However, in the vicinity of the Lena Delta the surface SPM concentration is strongly dependent on river discharge (e.g. Burenkov et al., 1997; Wegner et al., 2003). Most of the sediment transport is taking place in the bottom nepheloid layer. It is permanently present during the open water season with decreasing SPM concentrations from south to north and particles are likely introduced by river input, coastal erosion or resuspension of bottom material (Burenkov et al., 1997; Lisitsin et al., 2000; Wegner et al., 2003, 2005).

To study the interannual variability of SPM on the Laptev Sea shelf, detailed oceanographic, optical, and hydrochemical surveys were carried out during the TRANSDRIFT XII and XIV expeditions in the summers 2007 and 2008 within the Russian-German cooperation "Laptev Sea System", (Kassens et al., 2010; Fig. 1). In addition, two year-long oceanographic moorings equipped with Acoustic Doppler Current Profilers (ADCP), as well as with temperature, salinity, and turbidity recorders were deployed north of the Lena Delta to study oceanographic processes in the frontal zone between the river- and shelf-dominated waters (Fig. 1). For a better spatial resolution of transparency and attenuation in the water column, we employed Ocean Color satellite data (MERIS onboard ENVISAT). 


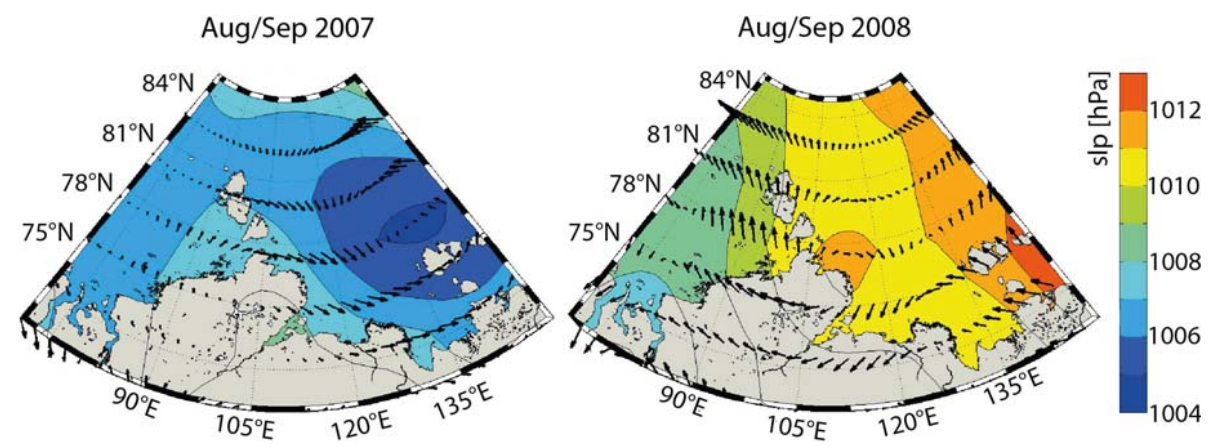

Fig. 2. Average sea level pressure (slp [hPa]) and prevailing wind directions during August to September 2007 and 2008 . NCEP Reanalysis data provided by the NOAA/OAR/ESRL PSD, Boulder, Colorado, USA, from their website at http://www.esrl.noaa.gov/psd/.

Our field studies coincided first, with the anomalous sea ice extent (Stroeve et al., 2012) and maximum Siberian river discharge (Shiklomanov and Lammers, 2010) in summer 2007, and second, covered two summers with opposite atmospheric circulation patterns over the Laptev Sea: cyclonic circulation in summer 2007 and anticyclonic circulation in 2008 (Abrahamsen et al., 2009; Fig. 2). This unique data set enables us for the first time to analyze and discuss the interannual variations in SPM dynamics on the Laptev Sea shelf under different atmospheric forcing and their implication for optical properties.

\section{Material and methods}

\subsection{Suspended matter and turbidity measurements}

A seapoint turbidity meter connected to a CTD (Conductivity Temperature Depth Meter; SBE19plus, Seabird, USA) was used in order to collect water column turbidity, salinity, and temperature measurements at a total of 177 stations during TRANSDRIFT XII and XIV expeditions in August/September 2007 and 2008. The turbidity meter emits light of $880 \mathrm{~nm}$ wavelength with a sampling rate of $10 \mathrm{~s}^{-1}$. It detects light scattered by particles within the water column and generates an output voltage proportional to particles in the water column. The output is given in Formazine Turbidity Unit (FTU), a calibration unit based on formazine as a reference suspension. Generally samples within the upper $1.50 \mathrm{~m}$ may be biased by air bubbles (Johnson et al., 2000; Puleo et al., 2006) and were hence discarded.

A total of 434 water samples of $0.5 \mathrm{~L}$ each were collected from different water depths to obtain the SPM concentrations by using the traditional filtering and weighing procedures and to calibrate the optical backscatter. All SPM concentrations obtained from water samples $\left(\mathrm{SPM}_{\text {filter }}\right) \leq 0.3 \mathrm{mg} \mathrm{L}^{-1}$ were set to $0.3 \mathrm{mg} \mathrm{L}^{-1}$, as the elutable portion of the used filters (MILLIPORE Durapore membrane filters $\emptyset 0.45$ microns) is $<0.3 \mathrm{mg} \mathrm{L}^{-1}$. All turbidity measurements were correlated with corresponding in situ water samples to obtain accuracy by taking the effects of different mineralogy, varying particle darkness, and salinity of ambient water on the response of the turbidity meter into account (Maa et al., 1992; Sutherland et al., 2000).

Additionally the ADCP's echo intensity of the bottommooring stations Anabar and Khatanga (see below) have been used as a relative measure for SPM concentration with increased echo intensity, indicating increased SPM concentration (e.g. Gartner and Cheng, 2001; Wegner et al., 2006). As the intensity of the backscattered acoustic signal (echo intensity) provides information on particle concentration, ADCPs have gained acceptance for the measurements of SPM transport dynamics (e.g. Holdaway et al., 1999; Rose and Thorne, 2001; Wegner et al., 2006).

\subsection{Current measurements and the estimation of threshold current velocity}

We analyzed current speed and direction for September 2007 and 2008, obtained with downward-looking ADCPs (WHSentinel $1200 \mathrm{kHz}$, RD-Instruments) at the bottom-mooring stations Anabar and Khatanga (Kassens at al., 2010). Current profiles were collected in 30 min intervals and a bin size of $0.2 \mathrm{~m}$, and resolved the depths between $27.42-31.62 \mathrm{~m}$ (Anabar) and 38.42-42.62 m (Khatanga) in 2007 and between 28.11-32.71 m (Anabar) and 38.11-42.71 m (Khatanga) in 2008. For a detailed description of the ADCP data, refer to Hoelemann et al. (2011) and Janout et al. (2013).

To examine the implications of currents for sediment transport, the ADCP data of the long-term mooring stations Anabar and Khatanga, respectively were used to estimate the threshold current velocity for incipient grain motion $\left(u_{\mathrm{cr}}\right)$ :

$u_{\mathrm{cr}}=7\left(\frac{z}{d_{50}}\right)^{1 / 7}\left(g(s-1) d_{50} \theta_{c r}\right)^{1 / 2}$,

where $z$ is the depth of flow, $d_{50}$ the median grain diameter, $g$ the acceleration due to gravity, $s$ is the relative density, and $\theta_{\mathrm{cr}}$ the threshold shields parameter by Soulsby and Whitehouse (1997). To estimate $u_{\mathrm{cr}}$, grain-size characteristics of 
Table 1. Positions, median grain size $\left(d_{50}\right)$ for the surface samples after Lindemann (1994), threshold shields parameter $\left(\theta_{\mathrm{cr}}\right)$, and threshold current velocity for incipient grain motion $\left(u_{\mathrm{cr}}\right)$ in the vicinity of the respective long-term mooring stations.

\begin{tabular}{llllllll}
\hline \multirow{2}{*}{ Surface samples } & \multicolumn{2}{l}{ Position of surface samples } & Water depth $[\mathrm{m}]$ & Long-term mooring & $d_{50}[\Phi]$ & $\theta_{\mathrm{cr}}^{\mathrm{b}}$ & $u_{\mathrm{cr}}\left[\mathrm{cm} \mathrm{s}^{-1}\right]^{\mathrm{c}}$ \\
\cline { 2 - 3 } & Lat. & Long. & & & & \\
\hline IK93 42-5 & $74^{\circ} 30.3^{\prime} \mathrm{N}$ & $127^{\circ} 19.8^{\prime} \mathrm{E}$ & 34 & Anabar & 4 & 0.135 & $34.63^{\mathrm{d}}$ \\
IK93 56-1 & $75^{\circ} \mathrm{N}$ & $123^{\circ} \mathrm{E}$ & 42 & Khatanga & 3.5 & 0.108 & $39.82^{\mathrm{d}}$ \\
\hline
\end{tabular}

${ }^{a}$ Kassens and Karpiy (1994); ${ }^{\mathrm{b}}$ estimated following Soulsby (1997); ${ }^{\mathrm{c}}$ estimated following Soulsby and Whitehouse (1997); ${ }^{\mathrm{c}} z=1.5 \mathrm{mab}$

surface samples were used (Table 1) according to Lindemann (1994).

\subsection{Oxygen and silicate measurements}

Water sampling for silicate ( $\mathrm{Si}$ ) and dissolved oxygen (DO) concentration was carried out with Niskin bottles. During both expeditions water samples for DO concentration of $100 \mathrm{~mL}$ each were subsampled into glass bottles, fixed by sequential adding of $1 \mathrm{~mL}$ of manganese chloride and $1 \mathrm{~mL}$ of potassium iodide/sodium hydroxide solution. The sample was mixed until the evenly distributed precipitate was formed. After precipitating, it was dissolved by the addition of $2 \mathrm{~mL}$ of sulfuric acid. The DO content was determined by titration with sodium thiosulphate using automatic burette ABU-80 following the modified Winkler method (Oradovsky, 1993).

During TRANSDRIFT XII in summer 2007 water samples for silicate were subsampled in $50 \mathrm{~mL}$ plastic bottles, frozen under $-20^{\circ} \mathrm{C}$ and analyzed photometrically with a SKALAR Sun Plus nutrient autoanalyzer (in range: $2-100 \mathrm{ppb}$ ); this was completed within one month in the Otto-Schmidt Laboratory, St. Petersburg, Russia, applying "Skalar" methods (US Environmental Protection Agency, 1983). During TRANSDRIFT XIV silicate water samples were subsampled in $125-\mathrm{mL}$ plastic bottles, added to Nessler cylinders at $35 \mathrm{~mL}$ for silicate analysis. In silicate samples, $1 \mathrm{~mL}$ of mixed reagent was added first. After a 10-min exposure, $1 \mathrm{~mL}$ oxalic and $1 \mathrm{~mL}$ of ascorbic acid solution were added sequentially to the sample. Samples were analyzed after a 30-min exposure with photo-colorimeter FC-3 (Oradovsky, 1993).

\subsection{Riverine fraction of sea water}

Water sampling for stable oxygen isotope $\left(\delta^{18} \mathrm{O}\right)$ was conducted with Niskin bottles in parallel to hydrochemical sampling. Sampling procedure and data analysis are described in detail by Bauch et al. $(2010,2013)$. The combined interpretation of $\delta^{18} \mathrm{O}$ composition of the water and salinity allows for the quantification of the different freshwater contributions in polar regions, i.e. river water and sea ice (Bauch et al., 1995). Both $\delta^{18} \mathrm{O}$ and salinity are conservative tracers only altered by phase transitions. River water in the Arctic is highly de- pleted in its $\delta^{18} \mathrm{O}$ stable oxygen isotope composition (Cooper et al., 2008) relative to marine waters. The contribution of sea ice processes can be separated from any mixture between marine and river water since it strongly influences salinity, whereas the $\delta^{18} \mathrm{O}$ signal remains nearly unaltered (Melling and Moore, 1995).

The river water and sea ice meltwater contributions can be quantified by applying a mass-balance calculation, which has been carried out in numerous studies in Arctic Ocean basins (e.g. Östlund and Hut, 1984; Bauch et al., 1995; Ekwurzel et al., 2001; Yamamoto-Kawai et al., 2008) and shelf regions (Macdonald et al., 1995; Cooper et al., 1997; Bauch et al., 2005). Thereby it is assumed that each sample is a mixture between marine water $\left(f_{\mathrm{mar}}\right)$, river runoff $\left(f_{\mathrm{r}}\right)$ and sea ice meltwater $\left(f_{\mathrm{i}}\right)$. Based on measurement precision and range of endmember values, calculated river water fractions are derived within $\pm 1 \%$. For further details on the method and selection of endmembers refer to Bauch et al. (2010).

\subsection{Ocean color satellite measurements}

For summer 2007 and 2008 ENVISAT-MERIS data of areas with minimum cloud coverage were processed towards optical higher level parameters using Beam-Visat4.9@ and the MERIS case2 regional processor (C2R). C2R uses neural network procedures for the retrieval of the atmospherically corrected water leaving reflectance and to derive apparent optical parameters such as attenuation coefficients $(k)$, the penetration depth $\left(Z_{90}\right)$ and calculated concentrations (chlorophyll, total suspended matter, and colored dissolved organic matter). The calculated optical MERIS C2R parameters such as minimum attenuation within the photosynthetically active radiation (PAR), wavelength region, $k_{\min }$, and $Z_{90}$, over which the seawater layer contributes $90 \%$ of the radiant energy emerging from the sea (Gordon and MacCluney, 1975), are useful indicators for transmissivity. For a detailed description of the ocean color satellite measurements refer to Heim et al. (2013). 


\section{Results}

\subsection{Distribution of the river plume and associated SPM and nutrient dispersion}

The surface salinity of the Laptev Sea shelf is strongly influenced by the high freshwater discharge of the River Lena and therefore comparably low throughout the shelf. Surface silicate concentrations $>10 \mu \mathrm{mol} \mathrm{L} \mathrm{L}^{-1}$ are generally considered a good indicator for the distribution of riverine waters during ice-free conditions (Rusanov et al., 1994; Pivovarov et al., 2004). According to the surface silicate distribution the river plume in 2007 was limited to latitudes between $75.5^{\circ} \mathrm{N}$ on the eastern shelf and $74.3^{\circ} \mathrm{N}$ north of the Lena Delta (Fig. 3b). However, during summer 2008 surface silicate concentrations $>10 \mu \mathrm{mol} \mathrm{L}^{-1}$ were observed as far north as $77.5^{\circ} \mathrm{N}$ on the eastern Laptev Sea shelf, and $76.5^{\circ} \mathrm{N}$ on the shelf area north of the Lena Delta (Fig. 3e). As an alternative proxy for the identification of riverine waters in the Laptev Sea we applied the $\delta^{18} \mathrm{O} /$ salinity-based water mass analysis, a well-established method for the Laptev Sea shelf (Bauch et al., 2005, 2009, 2010). A river water fraction of about $50 \%$ in the surface waters marks the boundary between riverand shelf-dominated waters. Accordingly, Lena River waters spread no further than $74.3^{\circ} \mathrm{N}$ in summer 2007 (Fig. 3c). In 2008 waters containing river water fractions $<50 \%$ spread up to $76.5^{\circ} \mathrm{N}$ on the eastern shelf, and up to $75.3^{\circ} \mathrm{N}$ in the central Laptev Sea (Fig. 3f). Thus, silicate and $\delta^{18}$ O-based definitions of river-influenced surface waters show the same principal pattern with further northwards spreading of the river plume during summer 2008 compared to 2007.

We used our vertically interpolated SPM concentration data to map the extent and thickness of the Lena River plume, characterized by SPM concentrations of $>1 \mathrm{mg} \mathrm{L}^{-1}$. In 2007, the turbid surface waters of the Lena River plume with a maximum SPM concentration of $9.1 \mathrm{mg} \mathrm{L}^{-1}$ showed a northwards extent to $\sim 75^{\circ} \mathrm{N}$, with a $10.9 \mathrm{~m}$ surface nepheloid layer in the vicinity of the Lena Delta (Fig. 4a). In 2008, the turbid surface waters extended further north $\left(76.8^{\circ}\right.$ north of the Lena Delta and $77.8^{\circ} \mathrm{N}$ on the eastern shelf), although the surface nepheloid layer was thinner $(2.6 \mathrm{~m})$ and SPM concentrations lower $\left(4.2 \mathrm{mg} \mathrm{L}^{-1}\right)$ than in 2007 (Fig. 4e).

The bottom nepheloid layer during summer 2007 was very prominent, with a maximum thickness of $11.4 \mathrm{~m}$ (Fig. 4a). On the eastern inner shelf, maximum bottom SPM concentrations were $59 \mathrm{mg} \mathrm{L}^{-1}$ and coincided with a maximum $\mathrm{Si}$ concentration of $31.4 \mu \mathrm{mol} \mathrm{L}-1$ and a minimum DO-concentration of $5 \mu \mathrm{mol} \mathrm{L}^{-1}$ (Fig. 4a, c, d). A second bottom SPM maximum, with concentrations up to $17.2 \mathrm{mg} \mathrm{L}^{-1}$, was observed within the frontal zone between the riverine surface waters and the shelf waters, coinciding with maximum in Si-concentration of $24.8 \mu \mathrm{mol} \mathrm{L}^{-1}$ and DO-minimum of $5.5 \mu \mathrm{mol} \mathrm{L}{ }^{-1}$ (Fig. $4 \mathrm{a}-\mathrm{d}$; section distance $300 \mathrm{~km}$ ). During summer 2008, the bottom nepheloid layer reached a thickness of up to $10.6 \mathrm{~m}$, although SPM
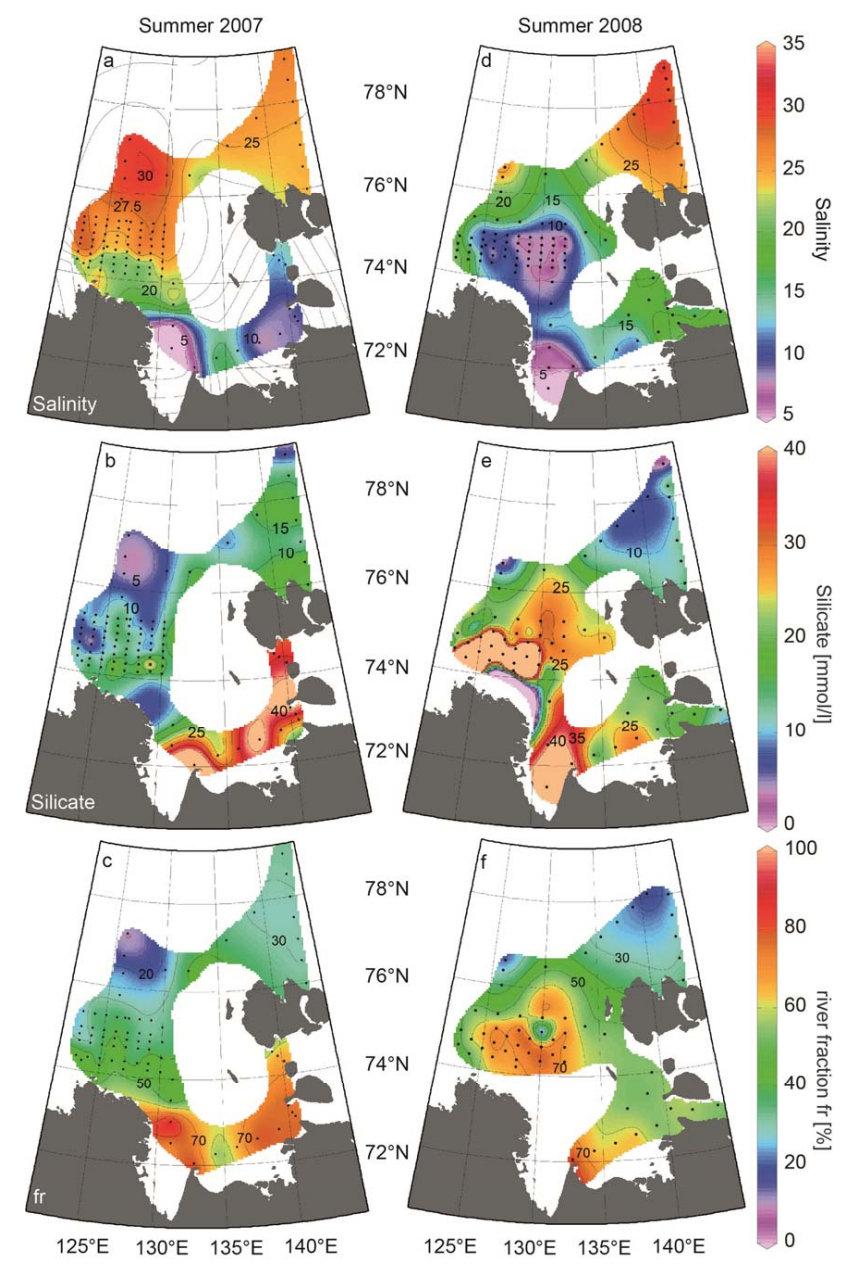

Fig. 3. The surface distribution of salinity (a, d; $[\mathrm{psu}])$, silicate concentration (b, e; $\left.\left[\mu \mathrm{mol} \mathrm{L}^{-1}\right]\right)$, and $\delta^{18} \mathrm{O}$-derived river water fraction fr $(\mathbf{c}, \mathbf{f} ;[\%])$ indicates the different spreading of river-dominated surface waters during TD XII (summer 2007) and TD XIV (summer 2008).

concentrations were four times lower (Fig. 4e). The first maximum of $12.2 \mathrm{mg} \mathrm{L}^{-1}$, coinciding with a maximum in Si-concentration of $32 \mu \mathrm{mol} \mathrm{L}-1$ and a minimum in DOconcentration of $5 \mu \mathrm{mol} \mathrm{L}{ }^{-1}$, was observed on the eastern inner shelf (Fig. 4e, g, h; section distance $0 \mathrm{~km}$ ). A second bottom SPM maximum of $7.06 \mathrm{mg} \mathrm{L}^{-1}$, coinciding with maximum Si-concentrations of $29 \mu \mathrm{mol} \mathrm{L}^{-1}$ and minimum DOconcentrations of $6.1 \mu \mathrm{mol} \mathrm{L}-1$, was measured beneath the riverine surface waters north of the Lena Delta (Fig. 4e-h; section distance $300 \mathrm{~km}$ ).

\subsection{Interannual variability of optical water column properties}

Evaluation of optical properties reveals distinct differences between 2007 and 2008. A strong correlation between turbidity meter measurements and filter measurements was found 


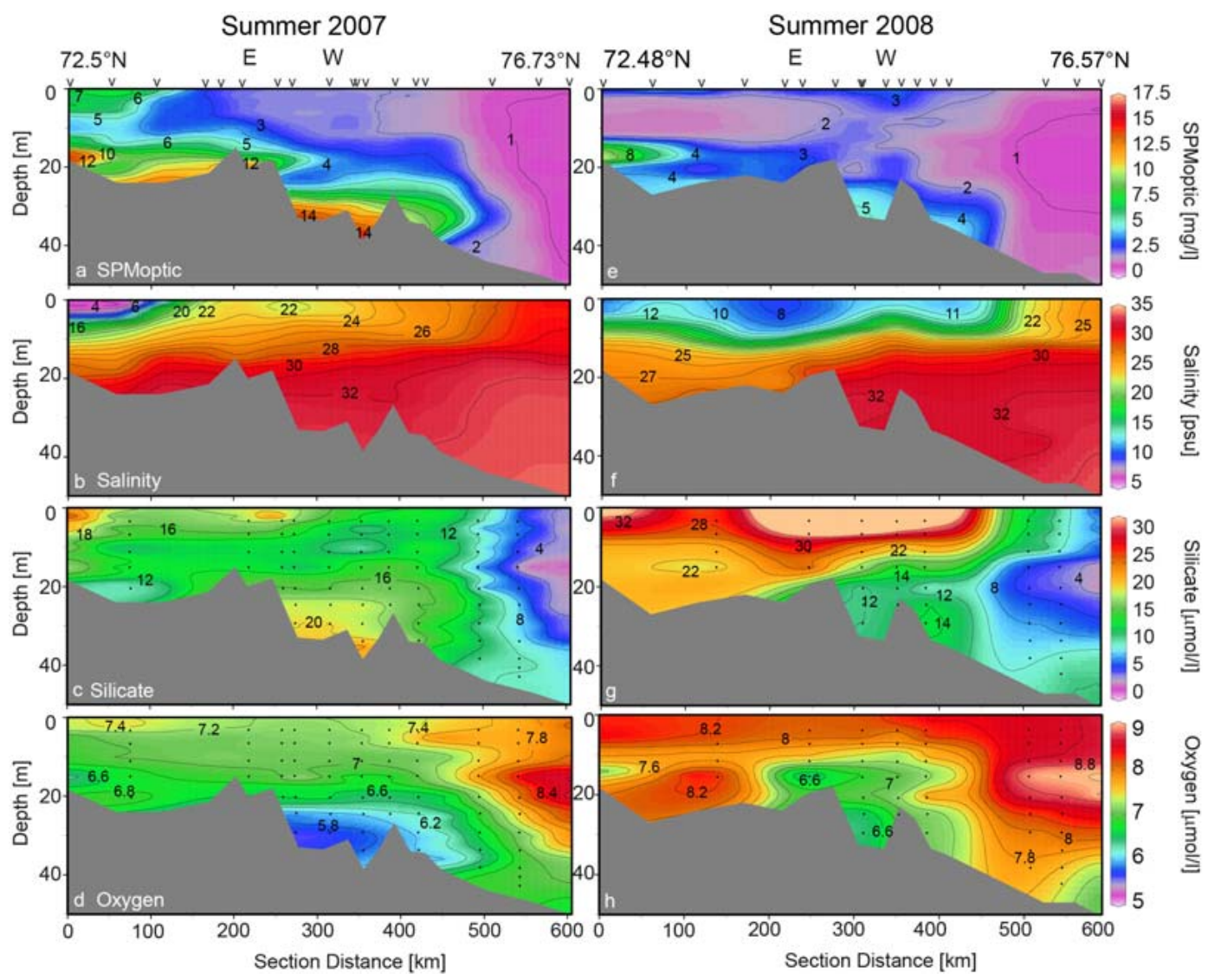

Fig. 4. A south-north section across the eastern Laptev Sea shelf during TD XII (summer 2007; sampling period in Julian days: 241-255)

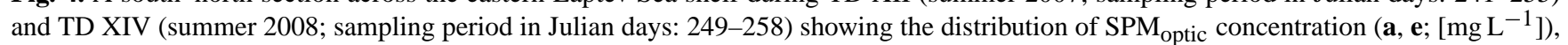
salinity (b, f; $[\mathrm{psu}])$, silicate concentration $\left(\mathbf{c}, \mathbf{g}\right.$; $\left.\left[\mu \mathrm{mol} \mathrm{L}{ }^{-1}\right]\right)$, and dissolved oxygen $\left(\mathbf{d}, \mathbf{h} ;\left[\mu \mathrm{mol} \mathrm{L}{ }^{-1}\right]\right)$. As density on Arctic shelf seas is mainly determined by salinity, salinity instead of density is shown here.

in both years in agreement with previous studies on the Laptev Sea shelf (Burenkov et al., 1997; Lisitsin et al., 2000; Wegner et al., 2003; Fig. 5). In summer 2008, the linear relation between the optical backscatter intensity $I$ in SPM concentration $\left(\mathrm{SPM}_{\mathrm{optic}}\right)$ can be expressed as $\mathrm{SPM}_{\mathrm{optic}}=$ $0.683+0.739 I$. This regression corresponds to measurements from summer 2000 (Wegner et al., 2003), a summer with prevailing southerly winds and a northward transport of the Lena freshwater plume similar to 2008. However, during the cyclonic summer 2007, characterized by the eastward spreading of riverine waters, the linear relation between $I$ and $\mathrm{SPM}_{\mathrm{optic}}$ concentration was different for stations south and north of $75^{\circ} \mathrm{N}$ (Fig. 5a, b): $\mathrm{SPM}_{\mathrm{optic}}=0.456+0.867 \mathrm{I}$ for stations north of $75^{\circ} \mathrm{N}$, and $\mathrm{SPM}_{\mathrm{optic}}=0.858+1.772 \mathrm{I}$ for stations south of $75^{\circ} \mathrm{N}$. The slope of the correlation for stations south of $75^{\circ} \mathrm{N}$ is two times steeper than the slope of the correlation found north of $75^{\circ} \mathrm{N}$. In general, the intensity of the backscattered infrared light of the turbidity meter is primarily a function of SPM concentration in front of the sensor (e.g. Hatcher et al., 2000; Hatje et al., 2001). Besides SPM concentration, sediment size has a secondary ef- fect on the backscatter signal (e.g. Sutherland et al., 2000; Downing, 2006). For silty sediments, the optical backscatter is about one-tenth higher than for sandy sediments (Sutherland et al., 2000; Downing, 2006). The absorption of light by colored dissolved organic matter (CDOM) might additionally affect the measured voltage of the turbidity meters due to the reduced light energy incident on scattering particles, as well as backscattered intensity (Downing, 2006). During summer 2007, the turbid Lena River waters were spread only on the inner eastern shelf, whereas in summer 2008 these waters were spread over a larger area (Fig. 4a, e). It can be assumed that the eastward transport of the turbid freshwater plume during summer 2007 lead to more turbid waters, with potentially higher grain sizes and therefore different optical properties on the inner shelf than on the shelf region north of $75^{\circ} \mathrm{N}$. This explains why it is necessary to apply two different algorithms for the inner and outer shelf regions during cyclonic atmospheric conditions and an associated eastward transport of the freshwater plume.

A similar pattern is reflected in the transmissivity data of the MERIS satellite images. The 2007 MERIS C2R data 

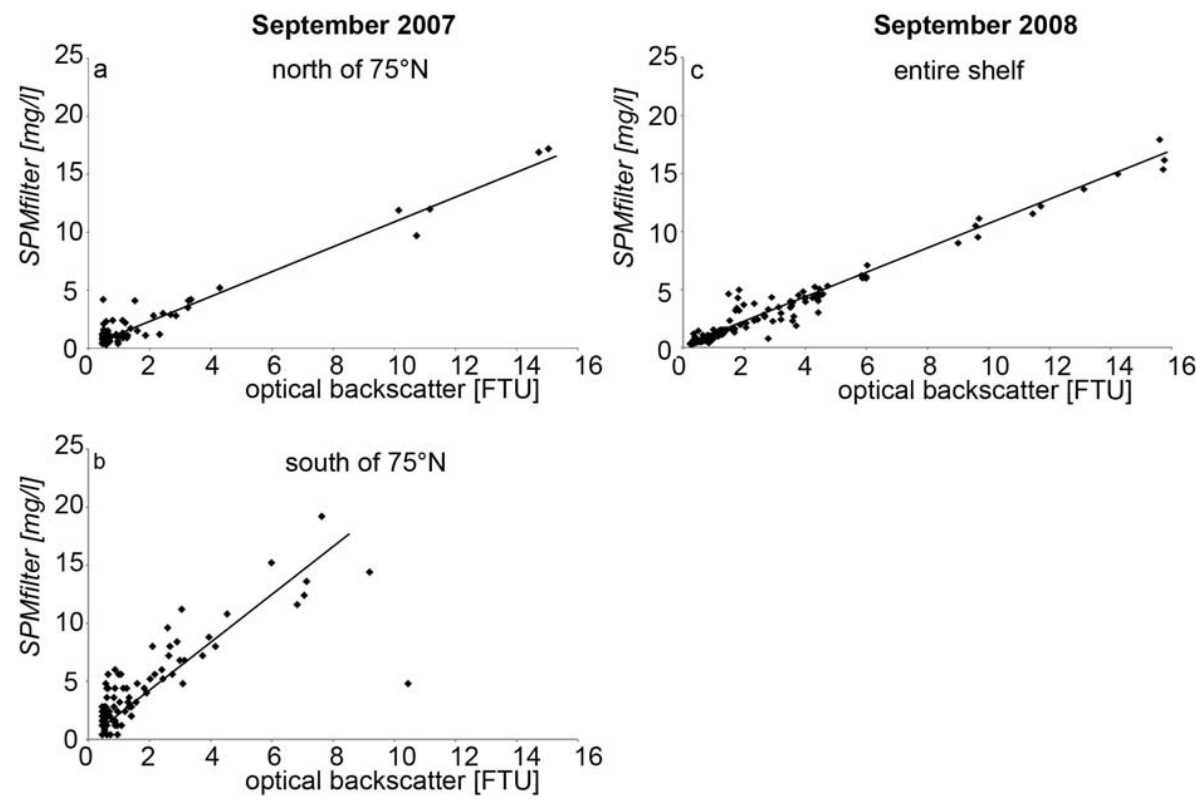

Fig. 5. Linear relation between concentrations derived from filtered water samples $\left(\mathrm{SPM}_{\text {filter }}\right)\left[\mathrm{mg} \mathrm{L}^{-1}\right]$ and optical backscatter measurements in Formazine Turbidity Units [FTU] in September 2007 (a: north of $75^{\circ} \mathrm{N}: R^{2}=0.949 ; p=0.01 ; n=101 ; \mathbf{b}$ : south of $75^{\circ} \mathrm{N}$ : $\left.R^{2}=0.889 ; p=0.01 ; n=86\right)$ and in $2008\left(\mathbf{c}: R^{2}=0.96 ; p=0.01 ; n=154\right)$.
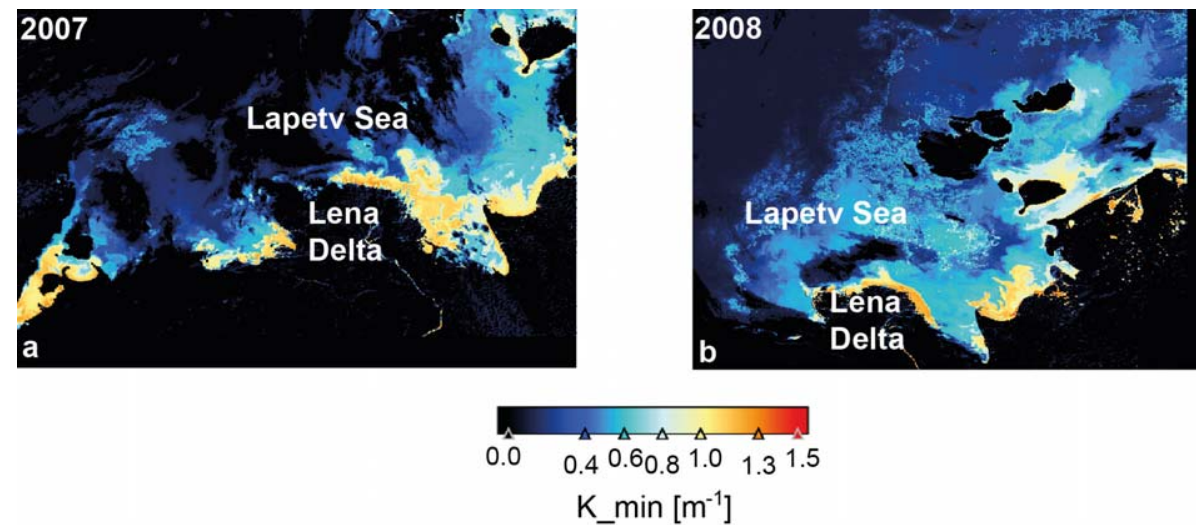

Fig. 6. ESA MERIS acquisition of the central southern Laptev Sea on 24 August 2007 (a) and 12 August 2008 (b) showing the different attenuation patterns in summer 2007 and 2008. The parameters are processed using MERIS Case 2 Regional C2R processor (attenuation: $\left.\mathrm{m}^{-1}\right)$. Land and clouds are masked in black.

show south-eastwards intrusion of transparent water masses $\left(\mathrm{kmin}<=0.3 \mathrm{~m}^{-1}\right)$ and well-developed turbidity fringes around the Lena River delta and the shallows (Fig. 6a). In contrast, in 2008, the optical water masses in the whole Laptev Sea Region are considerably less transparent (kmin $0.5 \mathrm{~m}^{-1}$; Fig. 6b).

\subsection{Bottom currents and echo intensity}

During September 2007, mooring Anabar was located directly within the frontal zone between river- and shelfdominated waters, while in 2008 this region was entirely dominated by Lena River waters. Mooring Khatanga was lo- cated west of the riverine surface waters during both years. Generally, peaks in echo intensity coincided with peaks in currents at both mooring stations. Current velocities and echo intensity at Anabar were higher compared to Khatanga, as seen in both maximum and mean values during both years (Table 2). During September 2007 currents and echo intensity were stronger than during 2008 (Table 2, Fig. 7). Maximum current speeds of $59.8 \mathrm{~cm} \mathrm{~s}^{-1}$ were recorded simultaneously with maximum echo intensity at Anabar during September 2007 following a storm event (Fig. 7). This was the only period when currents exceeded the critical shear stress velocity and therefore resuspension of bottom material took place. Thus it can be assumed that sediment 

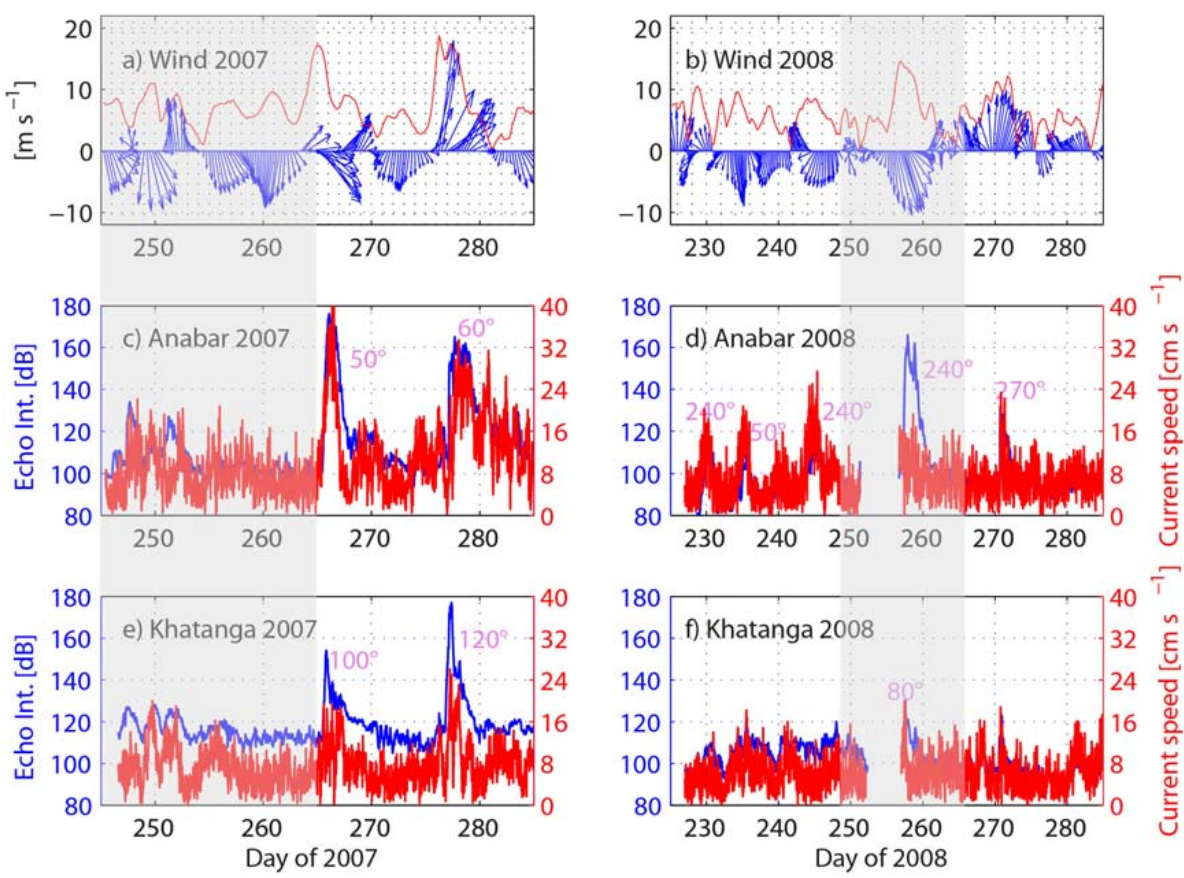

Fig. 7. Time series of one-day average wind speed $\left[\mathrm{m} \mathrm{s}^{-1}\right]$ and direction $(\mathbf{a}, \mathbf{b}), 6$-h running mean current speed [cm s$\left.{ }^{-1}\right]$, and echo intensity [dB] during August to September 2007 and 2008 at bottom moorings Anabar (c, d) and Khatanga (e, f). Current directions are given for the peaks in echo intensity when most sediment transport is assumed to take place. The directions are one-day averaged $\mathrm{u}$ - and $\mathrm{v}$ current components. NCEP Reanalysis data provided by the NOAA/OAR/ESRL PSD, Boulder, Colorado, USA, from their Web site at http://www.esrl.noaa.gov/psd/. The grey shaded area marks the measuring period of the section in Fig. 4.

entrainment due to resuspension of bottom material takes place mainly after storm events. The predominant mode of transport in this area is suspended load. During 2007 high bottom currents, coinciding with peaks in echo intensity at both moorings, were associated with southwesterly high speed winds (Fig. 7). Bottom currents during these periods were directed towards northeast. In contrast, the predominant bottom current direction at mooring Anabar during periods with high bottom currents and peaks in echo intensity in 2008 was southwest (Fig. 7). Only during one period was a peak in echo intensity detected when bottom currents were low (Fig. 7d). This is associated to a storm event with wind from north. Therefore turbid bottom waters were probably advected from the inner shelf area, causing higher SPM concentration in the bottom nepheloid layer.

\section{Discussion}

During the summer 2007, the surface salinity over the eastern Laptev Sea shelf exceeded the climatic mean by $\sim 2$ standard deviations (Dmitrenko et al., 2010), likely associated with the eastward wind-forced diversion of the Lena River freshwater plume because of a low sea level-pressure cell centered over the central Laptev Sea. The mean $(0-15 \mathrm{~m})$ salinity along the cross-shelf transect was 24.6 in 2007 and 17.9 in 2008 (Fig. 4), while the lower layer (>20 m) salinities were nearly similar, hence stratification in 2008 was far stronger than in 2007. As opposed to 2007 , when only a small proportion of riverine waters was transported onto the mid- and outer shelf, much of the shelf was dominated by the Lena River plume in summer 2008. This is consistent with statistical evaluations of historical ocean data by Dmitrenko et al. (2008), who suggest that approximately $500-600 \mathrm{~km}^{3}$ of freshwater is lost from the eastern Siberian shelf towards the deep Arctic Ocean through the northeastern Laptev Sea during anticyclonic summers. During cyclonic summers it is assumed that the freshwater is equally distributed between the Laptev and the east Siberian seas.

The transport of SPM in the upper water column is clearly linked to the distribution of the riverine surface waters. This is reflected in the overall SPM surface concentration of the surface nepheloid layer as well as in the spatial distribution of turbid waters. In general, the surface nepheloid layer on the Laptev Sea shelf is mainly related to the abundance of phytoplankton and zooplankton (e.g. Abramova and Tuschling, 2005). However, in the river-dominated shelf region, the surface layer is composed of both SPM and algal material (Burenkov et al., 1997; Wegner et al., 2003). Direct (SPM filter) as well as indirect SPM measurements $\left(\mathrm{SPM}_{\mathrm{optic}}\right)$ clearly reflect the same concentration and distribution patterns. $S M_{\text {optic }}$ concentration in the surface layer (upper $12 \mathrm{~m}$ ) on the inner shelf was considerably higher in 2007 and exceeded the mean 
Table 2. Summary of current speed $\left[\mathrm{cm} \mathrm{s}^{-1}\right]$ and echo intensity of the acoustic backscatter $[\mathrm{dB}]$ as a relative measure of SPM concentration at the bottom mooring stations Anabar and Khatanga for September 2007 and 2008 at different depth levels.

\begin{tabular}{|c|c|c|c|c|c|}
\hline Bottom mooring & $\begin{array}{c}\text { Time } \\
\mathrm{mm} / \mathrm{dd} / \mathrm{yy}\end{array}$ & Bin/depth & $\begin{array}{l}\text { Current speed max } \\
\qquad\left[\mathrm{cm} \mathrm{s}^{-1}\right]\end{array}$ & $\begin{array}{l}\text { Mean current speed } \\
\qquad\left[\mathrm{cm} \mathrm{s}^{-1}\right]\end{array}$ & $\begin{array}{c}\text { Echo intensity max } \\
{[\mathrm{dB}]}\end{array}$ \\
\hline \multirow[t]{3}{*}{ Anabar, $1200 \mathrm{kHz}$} & 09/03-09/30/07 & $\begin{array}{l}\text { bin } 1 / 27.42 \mathrm{~m} \\
\quad 4.58 \mathrm{mab}\end{array}$ & 59.8 & 12.16 & 207 \\
\hline & & $\begin{array}{c}\text { bin } 13 / 29.82 \mathrm{~m} \\
2.18 \mathrm{mab}\end{array}$ & 58.9 & 11.34 & 178 \\
\hline & & $\begin{array}{c}\text { bin } 22 / 31.62 \mathrm{~m} \\
0.38 \mathrm{mab}\end{array}$ & 41.5 & 8.64 & 176 \\
\hline \multirow[t]{3}{*}{ Khatanga $1200 \mathrm{kHz}$} & 09/03-09/31/07 & $\begin{array}{l}\text { bin } 1 / 38.42 \mathrm{~m} \\
5.2 \mathrm{mab}\end{array}$ & 25.0 & 8.78 & 182 \\
\hline & & $\begin{array}{c}\text { bin } 13 / 40.82 \mathrm{~m} \\
2.18 \mathrm{mab}\end{array}$ & 24.8 & 8.26 & 150 \\
\hline & & $\begin{array}{c}\text { bin } 22 / 42.62 \mathrm{~m} \\
0.38 \mathrm{mab}\end{array}$ & 20.0 & 7.1 & 154 \\
\hline \multirow[t]{3}{*}{ Anabar $1200 \mathrm{kHz}$} & 09/12-09/30/08 & $\begin{array}{l}\text { bin } 1 / 28.11 \mathrm{~m} \\
4.89 \mathrm{mab}\end{array}$ & 27.3 & 9.03 & 192 \\
\hline & & $\begin{array}{c}\text { bin } 13 / 30.51 \mathrm{~m} \\
2.49 \mathrm{mab}\end{array}$ & 28.2 & 7.55 & 166 \\
\hline & & $\begin{array}{c}\text { bin } 24 / 32.71 \mathrm{~m} \\
0.29 \mathrm{mab}\end{array}$ & 23.4 & 7.14 & 166 \\
\hline \multirow[t]{3}{*}{ Khatanga $1200 \mathrm{kHz}$} & 09/12-09/30/08 & $\begin{array}{l}\text { bin } 1 / 38.11 \mathrm{~m} \\
4.89 \mathrm{mab}\end{array}$ & 23.0 & 8.07 & 183 \\
\hline & & $\begin{array}{c}\text { bin } 13 / 40.51 \mathrm{~m} \\
2.49 \mathrm{mab}\end{array}$ & 20.0 & 7.2 & 150 \\
\hline & & $\begin{array}{c}\text { bin } 24 / 42.71 \mathrm{~m} \\
0.29 \mathrm{mab}\end{array}$ & 20.0 & 6.54 & 130 \\
\hline
\end{tabular}

$\mathrm{SPM}_{\text {optic }}$ concentration in 2008 by a factor of 2 (Fig. 4a, e). But on the other hand, the surface nepheloid layer in the anticyclonic summer 2008 reached further north, suggesting an increased surface SPM transport onto the mid-shelf (Fig. 4a, e).

Noticeably, maximum near-bottom current speeds in 2007 were twice as high as in 2008, exceeding $u_{\mathrm{cr}}$ and causing resuspension of bottom material (Table 2, Fig. 7). The mean $\mathrm{SPM}_{\text {optic }}$ concentration in the bottom nepheloid layer (the lowest $12 \mathrm{~m}$ ) along the transect in Fig. 4 was $3.5 \mathrm{mg} \mathrm{L}^{-1}$ and about 1.2 times higher than in 2008 (Fig. 4a, e). The bottom SPM maximum coincided with Si-maximum and DOminimum, a typical characteristic for resuspension of bottom material. Furthermore, the time series of echo intensity from the ADCPs show sudden increases in echo intensity when current velocities peak, which is most likely associated with the resuspension of bottom material. Thus it can be assumed that sediment entrainment due to resuspension of bottom material takes place mainly after storm events. Besides riverine input and bottom currents, waves are assumed to be a third principal factor to control sediment transport on the Laptev Sea shelf during the ice-free season. Wave parameters in the Laptev Sea are dependent on the extent of open water, thus from the wind fetch (Pavlov et al., 1996). However, model results from the coastal zone along Beaufort Sea point to the greater importance of storms than of fetch (Overdeem et al., 2011). Applying the only available wave parameters from Timokhov (1994) and Pavlov et al. (1996) suggest that waves during the ice-free conditions generally start to strongly influence the bottom only up to about $4 \mathrm{~m}$ water depth (Wegner et al., 2005). All studied stations were in water depths $>15 \mathrm{~m}$. Thus, the influence of waves for sediment transport processes is assumed to be moderate for this study.

Additionally, lateral advection of turbid bottom waters from the inner shelf seems to increase the SPM concentration within the bottom nepheloid layer as well. Furthermore, the overall proportion of resuspended material in the bottom layer was larger during 2007 compared to summer 2008, as well as the maximum SPM $_{\text {optic }}$ concentration, which exceeded the 2008 measurements with concentrations up to three times higher in 2007 (Fig. 8). Therefore it appears likely that both the surface and the bottom SPM transport are tightly coupled to the surface distribution of riverine waters on the Laptev Sea shelf. During the cyclonic summer 2007, turbid mixing, resuspension and enhanced transport of bottom material took place associated to the eastwards spreading of the freshwater plume. The prevailing transport direction near the bottom after storm events was towards northeast. During the anticyclonic summer of 2008, the northwards spreading of riverine waters and the resulting stronger 

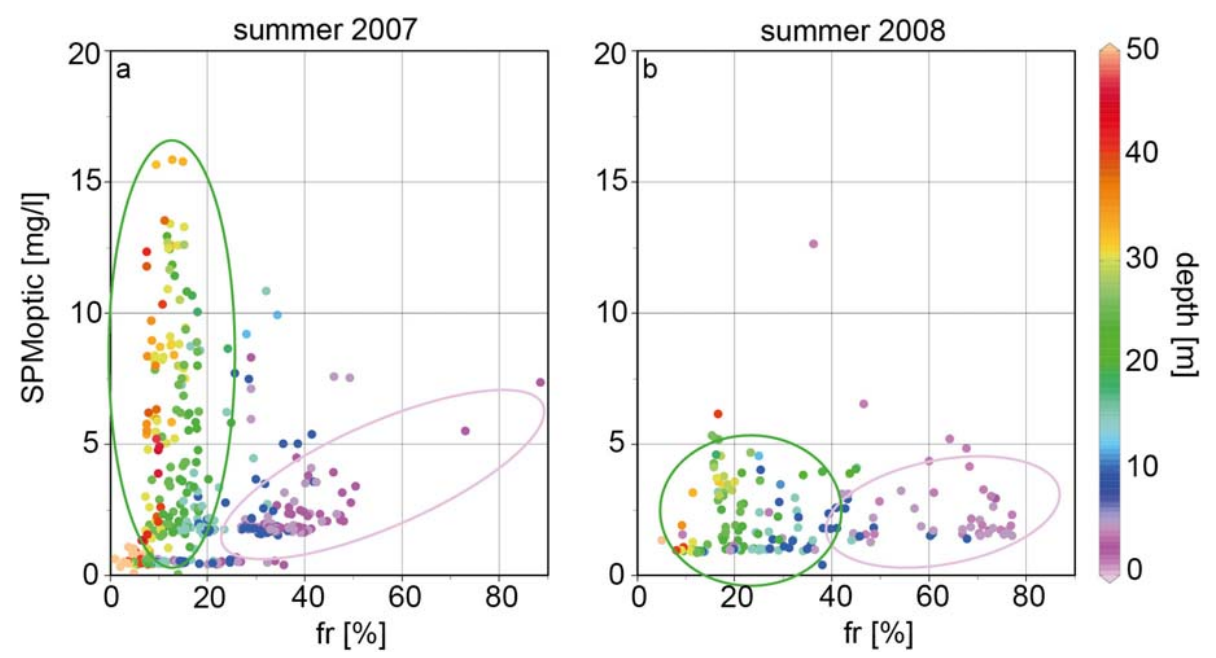

Fig. 8. Scatter plot of SPMoptic and riverine fraction along the section in Fig. 4 during TD XII (summer 2007) and TD XIV (summer 2008). Green circles mark the typical fr/SPMoptic relation for the bottom nepheloid layer. Purple circles mark the characteristic relation for the riverine-influenced surface nepheloid layer.

stratification on the central Laptev Sea shelf seem to prevent turbulent mixing and thus limits bottom SPM transport.

In general, the surface salinity east of the Lena Delta is assumed to be relatively stable with a standard deviation between 2 and 4 psu and invariant to atmospheric forcing and unaffected by river runoff on an annual basis (Dmitrenko et al., 2005). However, the surface SPM distribution and concentration show interannual variations also on the southeastern shelf: the surface $\mathrm{SPM}_{\text {optic }}$ concentrations are higher during the cyclonic summer 2007 (Fig. 8). Nevertheless, the difference between the 2007 and 2008 SPM concentrations, within both the surface and the bottom nepheloid layers, are highest on the central Laptev Sea shelf (Fig. 4a, e), coinciding with interannual salinity variations (Dmitrenko et al., 2005). The middle shelf is assumed to be the area most variant to the atmospheric circulation and mainly controlled by the wind-driven distribution of the river water.

The different SPM transport dynamics have an impact on the optical properties of the water column, as revealed in the turbidity measurements as well as in the Ocean Colour MERIS satellite data, with higher turbidity, less transmissivity and increased light absorption on the eastern inner shelf during cyclonic summers. Future multi-disciplinary studies, in combination with remote sensing, will improve our knowledge regarding the impact of the optical properties and improve the algorithms to translate remote sensing data in e.g., chlorophyll SPM and CDOM (Colored Dissolved Organic Matter) concentrations (see also Heim et al., 2013).

\section{Summary}

Sampling carried out during two Laptev Sea summer expeditions in 2007 and 2008 allows for new insights regarding the role of Lena River freshwater on sediment dynamics on this shelf. The prevailing atmospheric conditions were opposite during these two years, with predominantly shorewarddirected winds (cyclonic) in 2007 and northwards winds (anticyclonic) in 2008, which had immediate consequences for the distribution of the Lena freshwater plume and the sediment dynamics in the surface and bottom nepheloid layers. During summers with cyclonic atmospheric circulation patterns and an eastward transport of the Lena freshwater plume, it can be assumed that the surface SPM concentration on the southeastern shelf is increased, causing less transmissivity and probably increased light absorption, while surface SPM concentrations in the central and northern Laptev Sea are relatively low. Due to a weakly stratified water column and higher bottom current velocities, the bottom transport of SPM as well as the SPM concentration within the bottom nepheloid layer can be expected to be considerably higher. During anticyclonic summers, the surface SPM transport increases and reaches far out onto the middle-shelf, whereas the bottom transport and SPM concentration is diminished. Therefore we assume that the SPM dynamics in both the surface and bottom nepheloid layers are associated with the distribution of river-dominated surface waters and thus linked to the prevailing atmospheric circulation patterns over the Laptev Sea and the adjacent Arctic Ocean during summer.

During the last two decades there has been a positive trend in mean cyclone depth and radius over the Eurasian Basin (Simmonds and Keay, 2009), inducing cyclonic circulation patterns and an eastward transport of the riverine waters on the Laptev Sea shelf. A continuation of this trend might not only impact the sediment budget but could also have negative consequences for the sensitive ecosystem on this shelf due to changes in nutrient availability and light penetration. 
Acknowledgements. We thank the scientists, crew members and captains of RV Ivan Petrov for their support during the expeditions, and two anonymous reviewers for their stimulating reviews of this manuscript. The study is part of the joint Russian-German project "Laptev Sea System", financed by German and Russian ministries (BMBF and MINPROMNAUKI).

The service charges for this open access publication have been covered by a Research Centre of the

Helmholtz Association.

Edited by: P. Overduin

\section{References}

Abrahamsen, E. P., Meredith, M. P., Falkner, K. K., Torres-Valdes, S., Leng, M. J., Alkire, M. B., Bacon, S., Laxon, S. W., Polyakov, I., and Ivanov, V.: Tracer-derived freshwater composition of the Siberian contintal shelf and slope following the extreme Arctic summer of 2007, Geophys. Res. Lett., 36, L07602, doi:10.1029/2009GL037341, 2009.

Abramova, E. and Tuschling, K.: A 12-year study of the seasonal and interannual dynamics of mesozooplankton in the Laptev Sea: Significance of salinity regime and life cycle patterns, Glob. Planet. Change, 48, 141-164, 2005.

ACIA: Arctic Climate Impact Assessment - Scientific Report, Cambridge University Press, Cambridge, 2005.

Anoshkin, A. F., Popov, I. K., Ushakov, I. E., and TRANSDRIFT II Shipboard Scientific Party: Hydro optical measurements in the Laptev Sea: Spatial distributions of light attenuation and chlorophyll fluorescence, Rep. Pol. Res., 176, 178-186, 1995.

Antonow, M., Fürst, B., Haase, V., Strobl, C., and Thiede, J.: Multiprobe suspension and current speed measurements: Aspects of sediment dynamics during free-up studies in the Laptev Sea, Rep. Pol. Res., 248, 75-79, 1997.

Bauch, D., Schlosser, P., and Fairbanks, R. F.: Freshwater balance and the sources of deep and bottom waters in the Arctic Ocean inferred from the distribution of $\mathrm{H}_{2}^{18} \mathrm{O}$, Progr. Ocean., 35, 53-80, 1995.

Bauch, D., Erlenkeuser, H., and Andersen, N.: Water mass processes on Arctic shelves as revealed from ${ }^{18} \mathrm{O}$ of $\mathrm{H}_{2} \mathrm{O}$, Glob. Planet. Change, 48, 165-174, doi:110.1016/j.gloplacha.2004.1012.1011, 2005.

Bauch, D., Dmitrenko, I. A., Wegner, C., Hoelemann, J. A., Kirillov, S. A., Timokhov, L. A., and Kassens, H.: Exchange of Laptev Sea and Arctic Ocean halocline waters in response to atmospheric forcing, J. Geophys. Res., 114, C05008, doi:10.1029/2008JC005062, 2009.

Bauch, D., Hoelemann, J. A., Willmes, S., Gröger, M., Novikhin, A., Nikulina, A., Kassens, H., and Timokhov, L.: Changes in distribution of brine waters on the Laptev Sea shelf in 2007, J. Geophys. Res., 115, C11008, doi:11010.11029/12010JC006249, 2010.

Bauch, D., Hoelemann, J. A., Nikulina, A., Wegner, C., Janout, M., Timokhov, L., and Kassens, H.: Coupling of local sea-ice melting and river water on the Siberian shelves, J. Geophys. Res., Oceans, 118, doi:10.1002/jgrc.20076, 2013.

Boé, J., Hall, A., and Qu, X.: September sea-ice cover in the Arctic Ocean projected to vanish by 2100 , Nature Geosci., 2, 341-343,
doi:10.1038/NGEO467, 2009.

Burenkov, V. I., Kuptzov, V. M., Sivkov, V. V., and Shevchenko, V. P.: Spatial distribution and size composition of suspended matter in the Laptev Sea in August-September 1991, Ocean., 37, 831837, 1997.

Carmack, E. C., Barber, D., Christensen, J., Macdonald, R. W., Rudles, B., and Sakshaug, E.: Climate variability and physical forcing of the food webs and the carbon budget on panarctic shelves, Progr. Ocean., 71, 124-181; doi:10.1016/j.pocean.2006.10.005, 2006.

Comiso, J. C., Parkinson, C. L., Gersten, R., and Stock, L.: Accelerated decline in the Arctic sea ice cover, Geoph. Res. Lett., 35, L01703, doi:10.1029/2007GL031972, 2008.

Cooper, L. W., McClelland, J. W., Holmes, R. M., Raymond, P. A., Gibson, J. J., Guay, C. K., and Peterson, B. J.: Flowweighted values of runoff tracers $\left(\delta^{18} \mathrm{O}, \mathrm{DOC}, \mathrm{Ba}\right.$, alkalinity) from the six largest Arctic rivers, Geophys. Res. Lett., 35, L18606, doi:18610.11029/12008GL035007, 2008.

Cooper, L. W., Whitledge, T. E., Grebmeier, J. M., and Weingartner, T.: The nutrient, salinity, and stable isotope composition of Bering and Chukchi seas waters in and near the Bering Strait, J. Geophys. Res., 102, 12563-12573, 1997.

Dmitrenko, I. A., Kirillov, S. A., Eicken, H., and Markova, N.: Wind-driven summer surface hydrography of the eastern Siberian shelf, Geophys. Res. Lett., 32, L14613, doi:10.1029/2005GL023022, 2005.

Dmitrenko, I. A., Kirillov, S. A., and Tremblay, L. B.: The longterm and interannual variability of summer freshwater storage over the eastern Siberian shelf: Implication for climate change, J. Geophys. Res., 113, C03007, doi:10.1029/2007JC004304, 2008.

Dmitrenko, I. A., Kirillov, S. A., Krumpen, T., Makhotin, M., Abrahamsen, E. P., Willmes, S., Bloshkina, E., Hölemann, J. A., Kassens, H., and Wegner, C.: Wind-driven diversion of summer river runoff preconditions the Laptev Sea coastal polynya hydrography: Evidence from summer-to winter hydrographic records of 2007-2009, Cont. Shelf Res., 30, 1656-1664, 2010.

Downing, J.: Twenty-five years with OBS sensors: The good, the bad, and the ugly, Cont. Shelf Res., 26, 2299-2318, doi:10.1016/j.csr.2006.07.018, 2006.

Eicken, H., Gradinger, R., Gaylord, A., Mahony, A., and Rigor, I: Sediment transport by sea ice in the Chuckchi and Beaufort Seas: Increasing importance due to changing ice conditions?, DeepSea Res. II, 52, 3281-3302, doi:10.1016/j.dsr2.2005.10.006, 2005.

Ekwurzel, B., Schlosser, P., Mortlock, R., and Fairbanks, R.: River runoff, sea ice meltwater, and Pacific water distribution and mean residence times in the Arctic Ocean, J. Geophys. Res., 106, 9075-9092, 2001.

Gartner, J. W. and Cheng, R. T.: The promises and pitfalls of estimating total suspended solids based on backscatter intensity from Acoustic Doppler Profilers, Fed. Interagency Sed. Conf., Reno, III-119-III-126, 2001.

Gordon, H. R. and McCluney, W. R.: Estimation of the depth of sunlight penetration in the sea for remote sensing, Appl. Optics, 14, 413-416, 1975.

Guay, C. K., Falkner, R. D., Muench, R. D., Mensch, M., Frank, M., and Bayer, R.: Wind-driven transport pathways for Eurasian Arctic river discharge, J. Geoph. Res., 106, 11469-11480, 2001. 
Hatcher, A., Hill, P., and Macpherson, P.: Spectral optical backscatter of sand in suspension: Effects of particle size, composition and color, Mar. Geol., 168, 115-128, 2000.

Hatje, V., Birch, G. F., and Hill, D. M.: Spatial and temporal variability of particulate trace metals in Port Jackson Estuary, Australia. Est. Coast. Shelf Science, 53, 63-77, 2001.

Heim, B., Doerffer, R., Overduin, P. P., Hoelemann, J. A., Wegner, C., Loginova, A., Abramova, E., Martynov, F., Gienther, F., and Lantuit, H.: Ocean Colour remote sensing in the Laptev Sea: Evaluation and Application, Biogeosciences Discuss., accepted, 2013.

Hoelemann, J. A., Schirmacher, M., and Prange, A.: Transport and distribution of trace elements in the Laptev Sea: First results of the TRANSDRIFT expeditions, Rep. Pol. Res., 176, 297-302, 1995.

Hoelemann, J. A., Kirillov, S., Klagge, T., Novikhin, A., Kassens, H., and Timokhov, L.: Near bottom water warming in the Laptev Sea in response to atmospheric and sea-ice conditions in 2007, Pol. Res., 30, 6425, doi:10.3402/polar.v30i0.6425, 2011.

Holdaway, G. P., Thorne, P. D., Flatt, D., Jones, S. E., and Prandle, D.: Comparison between ADCP and transmissometer measurements of suspended sediment concentration, Cont. Shelf Res., 19, 421-441, 1999.

Janout, M. A., Hölemann, J. A., and Krumpen, T.: Cross-shelf transport of warm and saline water in response to sea ice drift on the Laptev Sea shelf, J. Geophys. Res. Oceans, 118, 1-14, doi:10.1029/2011JC007731, 2013.

Johnson, D. R., Asper, V., McClimans, T., and Weidemann, A.: Optical properties of the Kara Sea, J. Geophys. Res., 105, 88058811, 2000.

Kassens, H. and Karpiy, V.: Russian-German Cooperation: The TRANSDRIFT I expedition to the Laptev Sea, Rep. Pol. Res., 151, 168 pp., 1994.

Kassens, H., Hölemann, J., Klagge, T., and Novikhin, A.: RussianGerman Cooperation Laptev Sea: Expeditions TRANSDRIFT XII, XIV, XVI, Summer 2007, 2008, 2009, unpubl. cruise report, 138 pp., 2010.

Kwok, R., Cunningham, G. F., Wensnahan, M., Rigor, I., Zwally, H. J., and Yi, D.: Thinning and volume loss of the Arctic Ocean sea ice cover: 2003-2008, J. Geophys. Res., 114, C07005, doi:10.1029/2009JC005312, 2009.

Létolle, R., Martin, J. M., Thomas, A. J., Gordeev, V. V., Gusarova, S., and Sidorov, I. S.: ${ }^{18} \mathrm{O}$ abundance and dissolved silicate in the Lena delta and Laptev Sea (Russia), Mar. Chem., 43, 47-64, 1993.

Lindemann, F.: Sonographische und sedimentologische Untersuchungen in der Laptev-See, sibirische Arktis, Diploma Thesis, University of Kiel, 75 pp., 1994.

Lisitsin, A. P., Shevchenko, V. P., and Burenkov, V. I.: Hydrooptics und suspended matter of Arctic seas, Atmosph. Ocean. Opt., 13, 61-71, 2000.

Lund-Hansen, L. C., Andersen, T. J., Holtegaard Nielsen, M., and Pejrup, M.: Suspended Matter, chl-a, CDOM, grain sizes, and optical properties in the Arctic Fjord-type estuary, Kangerlussuaq, West Greenland, during summer, Estuaries and Coasts, 33, 14421451, 2010.

Maa, J. P.-Y., Xu, J., and Victor, M.: Notes of the performance of an optical backscatter sensor for cohesive sediments, Mar. Geol., 104, 215-218, 1992.
Macdonald, W., Paton, D., Carmack, E., and Omstedt, A.: The freshwater budget and under-ice spreading of Mackenzie River water in the Canadian Beaufort Sea based on salinity and ${ }^{18} \mathrm{O} /{ }^{16} \mathrm{O}$ measurements in water and ice, J. Geophys. Res., 100, 895-919, 1995.

Melling, H. and Moore, R.: Modification of halocline source waters during freezing on the Beauford Sea shelf: Evidence from oxygen isotopes and dissolved nutrients, Cont. Shelf Res., 15, 89-113, 1995.

Oradovsky, S. G.: Marine water hydrochemical analysis guide, St. Petersburg, Hydgometeoizdat, 1993 (in Russian).

Östlund, H. and Hut, G.: Arctic Ocean water mass balance from isotope data, J. Geophys. Res., 89, 6373-6381, 1984.

Overeem, I., Anderson, R. S., Wobus, C. W., Clow, G. D., Urban, F. E., and Matell, N.: Sea ice loss enhances wave action at the Arctic coast. Geophys. Res. Lett., 38, L17503, doi:10.1029/2011GL048681, 2011.

Pavlov, V. K., Timokhov, L. A., Baskakov, G. A., Kulakov, M. Y., Kurazhov, V. K., Pavlov, P. V., Pivovarov, S. V., and Stanovoy, V. V.: Hydrometeorological regime of the Kara, Laptev, and East Siberian seas. Technical Memorandum APL-UW TM1-96, University of Washington, 179 pp., 1996.

Pivovarov, S., Hölemann, J. A., Kassens, H., Antonow, M., and Dmitrenko, I.: Dissolved oxygen, silicon, phosphorus and suspended matter concentrations during the spring breakup of the Lena River, in: Land-Ocean Systems in the Siberian Arctic: Dynamics and History, edited by: Kassens, H., Bauch, H. A., Dmitrenko, I., Eicken, H., Hubberten, H.-W., Melles, M., Thiede, J., and Timokhov, L., Springer-Verlag, Berlin, 251-264, 1999.

Pivovarov, S., Hölemann, J. A., Kassens, H., Piepenburg, D., and Schmid, M. K.: Laptev and East Siberian Seas, in: The Sea, edited by: Robinson, A. R. and Brink, K. H., Harvard University Press, 14, 1107-1133, 2004.

Puleo, J. A., Johnson, R. V., Butt, T., Kooney, T. N., and Holland, K. T.: The effects of air bubbles on optical backscatter sensors, Mar. Geol., 230, 87-97, 2006.

R-ArcticNET: A Regional, Electronic, Hydrometric Data Network for Russia: Russian Daily Discharge Data from NSF-funded UCLA/UNH project, Station data at Kusur accessible at http:// rims.unh.edu/data/station/station.cgi?station=6342, http://www. r-arcticnet.sr.unh.edu/v4.0/index.html, 2011.

Retamal, L., Vicent, W. F., Martineau, C., and Osburn, C. L.: Comparison of the optical properties of dissolved organic matter in two river-influenced coastal regions of the Canadian Arctic, Est Coast. Shelf Scienc., 72, 261-272, doi:10.1016/j.ecss.2006.10.022, 2007.

Retamal, L., Bonilla, S., and Vincent, W. F.: Optical gradients and phytoplankton production in the Mackkenzie River and the coastal Beaufort Sea, Pol. Biol., 31, 363-379, 2008.

Rose, C. P. and Thorne, P. D.: Measurements of suspended sediment transport parameters in a tidal estuary, Cont. Shelf Res., 21, 1551-1575, 2001.

Rusanov, V. P., Yakolev, N. I., and Buinevich, A. G.: The hydrochemical regime of the Arctic Ocean, Proceedings of AARI, 355, 1-144, 1994 (in Russian).

Serreze, M. C., Holland, M. M., and Stroeve, J.: Perspectives on the Arctic's shrinking sea-ice, Science, 315, 1533-1536, 2007.

Shiklomanov, A. I. and Lammers, R. B.: Record Russian river discharge in 2007 and the limits of analysis, Environ. Res. Lett., 4, 
doi:10.1088/1748-9326/4/4/045018, 2010.

Simmonds, I. and Keay, K.: Extraordinary September Arctic sea icereductions and their relationships with storm behavior over 1979-2008, Geophys. Res. Lett., 36, L19715, doi:10.1029/2009GL039810, 2009.

Soulsby, R. L.: Dynamics of marine sands, Thomas Telford Publications, 249 pp., 1997.

Soulsby, R. L. and Whitehouse, R. J. W.: Threshold of sediment motion in coastal environments, Pacific Coasts and Ports '97, Christchurch, 149-154, 1997.

Stramska, M., Stramski, D., Hapter, R., Kaczmarek, S., and Ston, J.: Bio-optical relationships and ocean algorithms for the north polar region of the Atlantic, J. Geophys. Res., 108, 3143, doi:10.1029/2001JC001195, 2003.

Stroeve, J., Serreze, M. C., Holland, M. M., Kay, J. E., Malanik, J., and Barrett, A. P.: The Arctic's rapidly shrinking sea ice cover: a research synthesis, Clim. Change, 110, 1005-1027, doi:10.1007/s10584-011-0101-1, 2012.

Sutherland, T. F., Lane, P. M., Amos, C. L., and Dowing, J.: The calibration of optical backscatter sensors for suspended sediment of varying darkness levels, Mar. Geol., 162, 587-597, 2000.

Tietsche, S., Notz, D., Jungclaus, J. H., and Marotzke, K.: Recovery mechanisms of summer sea ice, Geophys. Res. Lett., 38, L02707, doi:10.1029/2010GL045698, 2011.

Timokhov, L. A.: Regional characteristics of the Laptev and East Siberian seas: Climate, topography, ice phases, thermohaline regime, circulation, Rep. Pol. Mar. Res., 144, 15-31, 1994.

US Environmental Protection Agency: Methods for Chemical Analysis of Water and wastes, Cincinnati, Ohio. EPA 600/4-79/020, p. $460,1983$.
Vasseur, C., Mostajir, B., Nozais, C., Dennis, M., Fouilland, E., Klein, B., and Demers, S.: Effects of bio-optical factors on the attenuation of ultraviolet and photosynthetically available radiation in the North Water Polynya, northern Baffin Bay: ecological implications, Mar. Ecol. Progr. Ser., 252, 1-3, doi:10.3354/meps252001, 2003.

Walsh, J. E., Chapman, W. L., and Shy, T. L.: Recent Decrease of Sea Level Pressure in the Central Arcticm, J. Climate, 9, 480486, 1996.

Wegner, C., Hölemann, J. A., Dmitrenko, I., Kirillov, S. A., Tuschling, K., Abramova, E., and Kassens, H.: Suspended particulate matter on the Laptev Sea shelf (Siberian Arctic) during ice-free conditions, Est. Coast. Shelf Scienc., 57, 55-64, 2003.

Wegner, C., Hölemann, J. A., Dmitrenko, I., Kirillov, S., and Kassens, H.: Seasonal variations in sediment dynamics on the Laptev Sea shelf (Siberian Arctic), Glob. Planet. Change, 48, 126-140, 2005.

Wegner, C., Hoelemann, J. A., Klagge, T., Timokhov, L., and Kassens, H.: Application of ADCPs for long-term sedimenttransport monitoring in Arctic environments - examples from the Laptev Sea, OMAE 2006 - 25th International Conference in Offshore Mechanics and Arctic Enngineering, 4-9 June, Hamburg, Germany, OMAE2006-92551, 2006.

Yamamoto-Kawai, M., McLaughlin, F. A., Carmack, E. C., Nishino, S., and Shimada, K.: Freshwater budget of the Canada Basin, Arctic Ocean, from salinity, $\delta^{18} \mathrm{O}$, and nutrients, J. Geophys. Res., 113, C01007, doi:10.1029/2006JC003858, 2008.

Zhang, X., He, J., Zhang, J., Polyakov, I., Gerdes, R., Inoue, J., and $\mathrm{Wu}, \mathrm{P} .:$ Enhnaced poleward moisture transport and amplified northern high latitude wetting trend, Nature Climate Change, 3, 47-51, doi:10.1038/NCLIMATE1631, 2012. 